\title{
HUBUNGAN KONSUMSI SOFTDRINK, LINGKAR PINGGANG DAN AKTIVITAS FISIK DENGAN KADAR GLUKOSA DARA H PUASA PADA WANITA DEWASA.
}

\author{
Ken Nira Anjangsari, Muflihah Isnawati*)
}

Program Studi Ilmu Gizi Fakultas Kedokteran Universitas Diponegoro

J1.Dr.Sutomo No.18, Semarang, Telp (024) 8453708, Email : gizifk@ undip.ac.id

\begin{abstract}
Background:high blood glucose levels is an indicator of diabetes mellitus. WHO predicted that the number of people with diabetes in Indonesia would be increase to 21.3 million people in 2030. Several factors can increased of blood glucose levels such as the consumption of high-energy food intake, waist circumference and physical inactivity.

Objective:determine association between softdrink consumption, waist circumference, physical activity with fasting blood glucose levels in adult women.

Method:cross-sectional study involved 38 women who were selected by consecutive sampling. The measurement of waist circumference with a metline. Softdrink consumption was collected by Semi Quantitative Food Frequency Questionnaire and physical activity by International Physical Activity Questionnaire. Fasting blood glucose level was measured by the glucose oxidase method. The data was analyzed by shapiro wilk, bivariate analysis with rankspearman test.

Result:86,8\% subjects had normal fasting blood glucose levels. $68.4 \%$ of the subjects included to abdominal obesity and 52,6\% subjects consumed softdrinks >1 bottle/week. 50\% subjects were middle physical activity.There were no association between softdrinks consumption $(r=0,119, p=0,477)$, waist circumference $(r=0,117, p=0,485)$ and physical activity $(r=0,68, p=0,687)$ with fasting blood glucose levels, but there was association between softdrinks consumption with waist circumference $(r=0,407, p=0,11)$.

Conclusion:softdrinks consumption, waist circumference,physical activity are not related to blood glucose level in adult woman.
\end{abstract}

Keywords:physical activity, softdrinks consumption,blood glucose, waist circumference, adult women

\section{ABSTRAK}

Latar belakang:tingginya kadar glukosa darah dapat menjadi indikator awal terjadinya penyakit diabetes mellitus. WHO memprediksi bahwa Indonesia pada tahun 2030 akan mengalami peningkatan jumlah penderita diabetes sebesar 21,3 juta orang. Beberapa faktor yang dapat menyebabkan peningkatan kadar glukosa darah dalam tubuh adalah konsumsi asupan makanan berenergi tinggi seperti softdrink, lingkar pinggang yang besar dan kurangnya aktivitas fisik.

Tujuan:untuk mengetahui hubungan antara konsumsi softdrink, lingkar pinggang dan aktivitas fisik dengan kadar glukosa darah puasa(GDP) pada wanita dewasa.

Metode:studi crossectional yang melibatkan 38 wanita dewasa yang dipilih secara consecutive sampling. Data lingkar pinggang didapat melalui pengukuran dengan pita meteran. Data konsumsi softdrink dan aktivitas fisik didapatkan dari pengukuran dengan kuisioner. Data kadar GDP diukur dengan metode glukose oksidase. Analisa bivariat dengan uji rankspearman.

Hasil: 86,8\% subjek memiliki GDP normal, 68,4\% subjek termasuk obesitas abdominal dan 52,6\%subjek mengkonsumsi $>1$ botol softdrink/minggu. Aktivitas fisik subjek (50\%) tergolong tingkat sedang. Tidak terdapat hubungan antara konsumsi softdrink $(r=0,119, p=0,477)$, lingkar pinggang $(r=0,117, p=0,485)$ dan aktivitas fisik( $r=0,68, p=0,687)$ dengan kadar GDP pada wanita dewasa, tetapi terdapat hubungan antara konsumsi softdrink dengan lingkar pinggang $(r=0,407, p=0,11)$.

Simpulan:konsumsi softdrink, lingkar pinggang, dan aktivitas fisik tidak berhubungan dengan kadar GDP pada wanita dewasa.

Kata kunci:aktivitas fisik, konsumsi softdrink, glukosa darah, lingkar pinggang, wanita dewasa.

\section{PENDAHULUAN}

Diabetes Mellitus (DM) adalah suatu sindroma gangguan metabolisme yang ditandai dengan peningkatan kadar glukosa darah sebagai akibat dari gangguan sekresi insulin, gangguan efektifitas insulin atau keduanya. ${ }^{1}$ Studi yang dilakukan WHO menemukan jumlah pengidap penyakit DM di Indonesia mencapai peringkat keempat dunia (8,6 juta) setelah Amerika, China dan India, dan diprediksi meningkat menjadi 21,3 juta pada tahun $2030 .^{2}$ Sekitar 3,6\% orang dewasa berusia antara 20-44 tahun di Amerika mengalami diabetes. Data tahun 2009-2012, kadar glukosa darah puasa $37 \%$ orang dewasa usia 20 tahun keatas di Amerika mengalami prediabetes, (51\% lebih besar dari mereka yang berusia diatas 65 tahun). ${ }^{3}$ 
Data Kementerian Kesehatan RI tahun 2008, prevalensi DM di Indonesia sebesar 5,7\%. Data Dinas Kesehatan Kota Semarang, kasus DM merupakan penyakit tidak menular tertinggi kedua setelah hipertensi dengan presentase 20,7\%. Menurut WHO, di Indonesia terdapat 4,03 juta wanita menderita DM. ${ }^{4,5}$

Berdasarkan penelitian yang dilakukan pada 18.956 orang dewasa di Indonesia ditemukan bahwa prevalensi prediabetes sebesar $10 \%$. Prediabetes yaitu suatu keadaan yang dapat menyebabkan DM type 2 dan penyakit kardiovaskular dimana kadar glukosa darah diatas normal tetapi belum dapat dikatakan sebagai diabetes, apabila tidak dikontrol dengan baik kondisi prediabetes akan meningkat menjadi DM dalam kurun waktu 5-10 tahun. Prediabetes berpotensi hampir dua kali lebih tinggi mengalami risiko kardiovaskuler dibanding mereka tanpa IGT/IFG. Pada wanita dengan prediabetes yang menjadi diabetes memiliki risiko kejadian kardiovaskuler 3 kali lebih tinggi dibanding mereka yang menetap sebagai prediabetes. Ditemukan bahwa $61,5 \%$ prediabetes di Indonesia adalah wanita dan 40,9 \% mengalami obesitas. ${ }^{6.7,8}$ Penelitian di Jakarta, menemukan ada hubungan antara lingkar pinggang dengan kadar glukosa darah. ${ }^{9}$ Dari beberapa penelitian menunjukkan bahwa lingkar pinggang yang besar lebih banyak terjadi pada wanita daripada pria. ${ }^{10,11}$

Peningkatan taraf hidup masyarakat di negara maju dan kota besar memberikan dampak terhadap perubahan gaya hidup dan pola konsumsi masyarakat. Terjadinya pergeseran pola makan dikota-kota besar yang komposisinya terlalu tinggi kalori, tinggi lemak, tinggi karbohidrat terutama gula tetapi rendah serat serta jenis pekerjaan (aktivitas fisik) yang tidak banyak mengeluarkan energi (sedentary) memiliki kemungkinan resistensi insulin lebih besar yang mengakibatkan peningkatan faktor risiko sindroma metabolik yang dapat berpengaruh terhadap berbagai masalah kesehatan. ${ }^{12}$

Karbohidrat digolongkan menjadi dua yaitu karbohidrat kompleks dan karbohidrat sederhana terdiri dari monosokarida meliputi glukosa, galaktosa, serta fruktosa dan disakarida yang meliputi maltosa, sukrosa serta laktosa. Asupan fruktosa sehari-hari yang bersumber dari makanan dan minuman, jumlahnya semakin bertambah terutama dari penambahan gula termasuk sukrosa, hal ini menyebabkan terjadinya peningkatan prevalensi berbagai gangguan kesehatan, salah satunya penyakit diabetes. ${ }^{13}$ Sedikitnya dalam sekaleng softdrink terdapat sembilan sendok teh gula, kebutuhan gula dalam tubuh kita dianjurkan tidak boleh melebihi empat sendok teh perhari. ${ }^{14}$ Penambahan gula/sukrosa banyak terdapat pada produk softdrink. Softdrink (minuman ringan) terdiri dari minuman ringan berkarbonasi (yang mengandung karbondioksida), contoh coca cola, sprite, fanta, dll, sedangkan minuman ringan yang tidak berkarbonasi (yang tidak mengandung karbondioksida) contoh minuman teh hijau, minuman isotonik, minuman buah, dll. Dalam sekaleng softdrink sedikitnya terdapat sembilan sendok teh gula, padahal, kebutuhan gula dalam sehari tidak lebih dari empat sendok teh. Konsumsi softdrink di dunia menunjukkan angka 552 miliar liter atau 82,5 liter/orang dalam setahun. ${ }^{15}$

Konsumsi softdrink memberi dampak yang kurang baik bagi kesehatan yaitu menyebabkan berat badan bertambah, obesitas serta berisiko terhadap diabetes mellitus tipe 2, serangan jantung, kanker dan stroke. ${ }^{16}$ Penelitian pada wanita dewasa, menunjukan bahwa wanita yang mengkonsumsi softdrink lebih berisiko terkena diabetes dibandingkan wanita yang tidak mengkonsumsi minuman tersebut. Konsumsi softdrink meningkat dari $195 \mathrm{~mL}$ perhari menjadi $275 \mathrm{~mL}$ perhari pada total populasi. Hasil survei menunjukkan bahwa minuman bergula salah satunya softdrink dikonsumsi setiap hari oleh orang dewasa, hal ini menunjukkan bahwa asupan energi yang hanya bersumber dari minuman berkalori tinggi pada orang dewasa di Indonesia sebesar 450 kalori per hari sedangkan energi yang dibutuhkan oleh tubuh berkisar antara 1800-2800 per hari. Bila minuman manis yang dikonsumsi mencapai 450 kalori/hari, artinya lebih dari $20 \%$ kebutuhan kalori berasal dari minuman manis. ${ }^{17,18}$

Secara nasional hampir separuh penduduk $(48,2 \%)$ kurang melakukan aktifitas fisik. Menurut kelompok umur, kurang aktivitas fisik paling tinggi terdapat pada kelompok 75 tahun ke atas $(76 \%)$ dan umur $10-40$ tahun $(66,9 \%)$, perempuan $(54,5 \%)$ lebih tinggi dari laki-laki $(41,4 \%) .{ }^{5}$ Hal ini dapat menimbulkan kemungkinan resistensi insulin yang lebih besar. Aktivitas fisik merupakan salah satu faktor yang berperan dalam status gula gula darah dalam tubuh. Pola makan masyarakat yang cenderung tinggi kalori dan tidak disertai dengan aktivitas fisik yang cukup dapat meningkatkan risiko terkena DM. ${ }^{19}$

Berdasarkan latar belakang tersebut, peneliti tertarik untuk meneliti hubungan konsumsi softdrink, lingkar pinggang dan aktivitas fisik dengan kadar glukosa darah puasa pada wanita dewasa. 


\section{METODE}

\section{Karaterisitik subjek dan sampel}

Penelitian ini merupakan penelitian gizi masyarakat yang dilaksanakan pada bulan Mei-Juni 2014 di wilayah kerja Puskesmas Tlogosari Kulon, Semarang. Penelitian ini menggunakan desain penelitian deskriptik analitik dengan rancangan studi crossectional Subjek penelitian ini adalah warga kelurahan Sendangguwo, Semarang. Besar sampel dalam penelitian ini minimal yang didapatkan 34 orang, untuk menghindari kemungkinan drop out, maka dilakukan koreksi dengan menambahkan subjek menjadi 38 orang. Subjek diambil dengan metode consecutive sampling yaitu dengan menyebarkan undangan kepada seluruh wanita usia 20-44 tahun di Sendangguwo. Semua wanita yang datang dan sesuai dengan kriteria dimasukkan dalam penelitian sampai jumlah subjek terpenuhi yang sesuai dengan kriteria inklusi yaitu wanita dewasa usia 20-44 tahun, tidak hamil, tidak merokok, tidak mengkonsumsi obat penurun glukosa darah, bersedia menjadi subjek penelitian dengan mengisi informed consent.

Data yang dikumpulkan dalam penelitian ini adalah identitas subjek, lingkar pinggang, konsumsi softdrink, aktivitas fisik, kadar glukosa darah puasa, asupan makanan yang meliputi asupan energi, karbohidrat, lemak, dan serat. Variabel bebas dalam penelitian ini adalah : konsumsi softdrink, lingkar pinggang, dan aktivitas fisik. Variabel terikat adalah kadar glukosa darah puasa (GDP).

Konsumsi softdrink adalah gambaran banyaknya softdrink (minuman bersoda, minuman isotonik, minuman kotak, dan minuman manis lainnya) yang dikonsumsi subjek selama satu bulan terakhir yang diperoleh melalui Form Semi Quantitave Food Frequency, dan dinyatakan dalam $\mathrm{ml} /$ hari. ${ }^{20}$ Konsumsi softdrink digolongkan menjadi 0-1 botol/minggu dan $>1$ botol/minggu dengan ukuran botol $250 \mathrm{ml}$.

Lingkar pinggang (LP) merupakan hasil pengukuran pada pertengahan antara batas bawah tulang iga dan crista iliaca secara horizontal pada saat akhir ekspirasi dengan kedua tungkai dilebarkan 20-30 $\mathrm{cm}$ dengan menggunakan pita meteran dan dinyatakan dalam $\mathrm{cm}$, subjek diminta untuk tidak menahan perut. Subjek dikatakan obesitas abdominal apabila LP $>80 \mathrm{~cm}$ dan normal $\mathrm{LP} \leq 80$ untuk ukuran orang Asia. ${ }^{21}$

Aktivitas fisik adalah skor dari jenis (tingkat MET), frekuensi (jumlah menit aktivitas fisik/hari) dan durasi (jumlah hari/minggu) aktivitas fisik yang dilakukan subjek selama 7 hari yang diukur menggunakan International Physical Activity Questionaire (IPAQ) dan dinyatakan dalam MET-menit/minggu, dikatakan rendah $(<600)$, sedang (600-2999), tinggi ( $\geq 3000) .{ }^{22}$

Kadar glukosa darah puasa (GDP) merupakan konsentrasi glukosa dalam darah diukur dengan metode glukosa oksidase (GODPAP) setelah subjek berpuasa selama 8-10 jam dan dinyatakan dalam $\mathrm{mg} / \mathrm{dL}$, sehari sebelum subjek diambil darah peneliti mengingatkan kembali melalui pesan singkat, pengukuran dilakukan oleh tenaga analis kesehatan dari laboratorium kesehatan Dinas Kesehatan Provinsi Jawa Tengah. Kadar GDP disebut hipoglikemi $(<70 \mathrm{mg} / \mathrm{dL})$ normal (70$110 \mathrm{mg} / \mathrm{dL})$, prediabetes $(110-125 \mathrm{mg} / \mathrm{dL})$ dan DM (> $126 \mathrm{mg} / \mathrm{dL}$ ). ${ }^{23}$ Pengkategorian variabel bebas dan terikat digunakan untuk data distribusi subjek.

Analisis univariat digunakan untuk mendeskripsikan data primer. Semua variabel diuji normalitas datanya dengan menggunakan uji Shapiro-Wilk. Analisis bivariat dilakukan dengan menggunakan uji Rank Spearman karena hanya data lingkar pinggang dan serat yang terdistribusi normal.

\section{HASIL PENELITIAN}

\section{A. Karakteristik Subjek}

Sebanyak 38 orang wanita umur 28-42 tahun yang memenuhi kriteria inklusi berperan serta dalam penelitian ini dengan karakteristik seperti pada tabel 1 .

Tabel 1. Karakteristik Subjek

\begin{tabular}{lcc}
\hline Karakteristik Subjek & \multicolumn{2}{c}{ Frekuensi } \\
\cline { 2 - 3 } & $\mathrm{N}$ & $\%$ \\
\hline Umur(28-42 tahun) & 38 & 100 \\
\hline Pekerjaan & & \\
Ibu rumah tangga & 17 & 44,7 \\
Guru & 6 & 15,8 \\
Swasta & 7 & 18,4 \\
Buruh & 5 & 13,2 \\
Wirausaha & 3 & 7,9 \\
Jumlah & $\mathbf{3 8}$ & $\mathbf{1 0 0}$ \\
\hline
\end{tabular}




\begin{tabular}{lcc}
\hline Riwayat diabetes keluarga & & \\
Ada & 7 & 18,4 \\
Tidak ada & 31 & 81,6 \\
Jumlah & $\mathbf{3 8}$ & $\mathbf{1 0 0}$ \\
\hline
\end{tabular}

Tabel 1 menunjukkan, $44,7 \%$ subjek bekerja sebagai Ibu rumah tangga dan sebagian besar subjek $(77,5 \%)$ tidak memiliki riwayat diabetes keluarga.

\section{B. Analisis Data}

Tabel 2 menunjukkan rata-rata kadar glukosa darah puasa $90,08 \pm 33,98 \mathrm{mg} / \mathrm{dL}$, rata-rata konsumsi softdrink subjek $89,7 \pm 100,25 \mathrm{ml} /$ hari, rata-rata subjek memiliki lingkar pinggang 89,24 $\pm 11,96 \mathrm{~cm}$ dan rata-rata aktivitas fisik subjek $1594,1 \pm 1099,3$ MET-menit/minggu. Disamping itu, rata-rata asupan energi subjek $2391,8 \pm 216,5 \mathrm{kkal}$, rata-rata asupan karbohidrat $338,4 \pm 43,7$ gram, rata-rata asupan lemak $82,9 \pm 16,1$ gram, dan rata-rata asupan serat $15,1 \pm 3,3$ gram

Tabel 2. Nilai Minimum, maksimum, rerata dan standar deviasi Kadar Glukosa Darah Puasa, Konsumsi Softdrink, Lingkar Pinggang, Aktivitas Fisik, Asupan Energi, Karbohidrat, Lemak dan Serat Subjek

\begin{tabular}{lcccc}
\multicolumn{5}{c}{ Penelitian. } \\
\hline \multicolumn{1}{c}{ Variabel } & N & Min & Maks & Mean \pm SD \\
\hline Kadar glukosa darah puasa (mg/dL) & 38 & 67,6 & 238,7 & $90,08 \pm 33,98$ \\
Konsumsi softdrink (ml/hari) & 38 & 0 & 333,3 & $89,7 \pm 100,25$ \\
Lingkar pinggang (cm) & 38 & 70 & 115 & $89,24 \pm 11,96$ \\
Aktivitas fisik (MET-menit/minggu) & 38 & 480 & 4431 & $1594,1 \pm 1099,3$ \\
Asupan zat gizi : & & & & \\
- energi (kkal) & 38 & 2134,1 & 2960,1 & $2391,8 \pm 216,5$ \\
- $\quad$ karbohidrat (gram) & 38 & 285,8 & 481,1 & $338,4 \pm 43,7$ \\
- lemak (gram) & 38 & 56,3 & 122,7 & $82,9 \pm 16,1$ \\
- Asupan serat (gram) & 38 & 7,4 & 23,6 & $15,1 \pm 3,3$ \\
\hline
\end{tabular}

\section{Distribusi Frekuensi Subjek}

Tabel 3 menunjukkan bahwa sebagian besar subjek $(92,1 \%)$ memiliki kadar glukosa darah puasa normal, sebagian besar subjek $(52,6 \%)$ mengkonsumsi softdrink $>1$ botol/minggu, sebagian besar subjek $(68,4 \%)$ mengalami obesitas abdominal, dan sebagian besar aktivitas fisik yang dilakukan subjek $(50 \%)$ termasuk dalam kategori sedang.

Tabel 3. Distribusi Frekuensi Subjek Berdasarkan Kadar Glukosa Darah Puasa, Konsumsi Softdrink, Lingkar pinggang, Tingkat Aktivitas Fisik

\begin{tabular}{llcc}
\hline Variabel & \multicolumn{1}{c}{ Kriteria } & \multicolumn{2}{c}{ Frekuensi } \\
\cline { 3 - 4 } & & $\mathrm{N}$ & $\%$ \\
\hline Glukosa darah puasa & Hipoglikemi & 2 & 5,3 \\
& Normal & 33 & 86,8 \\
& Prediabetes & 1 & 2,6 \\
& DM & 2 & 5,3 \\
& Jumlah & $\mathbf{3 8}$ & $\mathbf{1 0 0}$ \\
\hline Konsumsi softdrink & 0-1 botol/minggu & 18 & 47,4 \\
& $>1$ botol/minggu & 20 & 52,6 \\
& Jumlah & $\mathbf{3 8}$ & $\mathbf{1 0 0}$ \\
\hline Lingkar Pinggang & Normal & 12 & 31,6 \\
& Obesitas & 26 & 68,4 \\
& abdominal & & \\
& Jumlah & $\mathbf{3 8}$ & $\mathbf{1 0 0}$ \\
\hline Tingkat aktivitas fisik & Rendah & 16 & 42,1 \\
& Sedang & 19 & 50 \\
& Tinggi & 3 & 7,9 \\
& Jumlah & $\mathbf{3 8}$ & $\mathbf{1 0 0}$ \\
\hline
\end{tabular}


D. Hubungan Konsumsi Softdrink, Lingkar Pinggang, dan Aktivitas Fisik dengan Kadar Glukosa Darah Puasa

Hubungan Konsumsi Softdrink dengan Kadar Glukosa Darah Puasa
Hasil penelitian menunjukkan tidak ada hubungan antara konsumsi softdrink dengan kadar GDP ( $\mathrm{r}=0,119, \mathrm{p}=0,477)$. Hasil uji korelasi hubungan antara konsumsi softdrink dengan kadar GDP dapat dilihat pada gambar 1 .

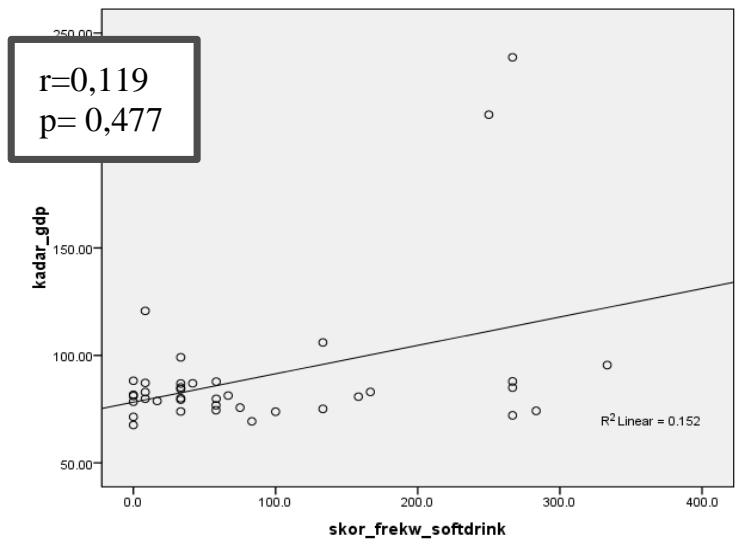

Gambar 1. Hubungan konsumsi softdrink dengan kadar GDP

Hubungan Lingkar Pinggang dengan Kadar

\section{Glukosa Darah Puasa}

Hasil penelitian menunjukkan tidak ada hubungan yang bermakna antara lingkar pinggang dengan kadar GDP ( $\mathrm{r}=0,117, \mathrm{p}=0,485)$. Hasil uji korelasi hubungan antara lingkar pinggang dengan kadar GDP dapat dilihat pada gambar2.

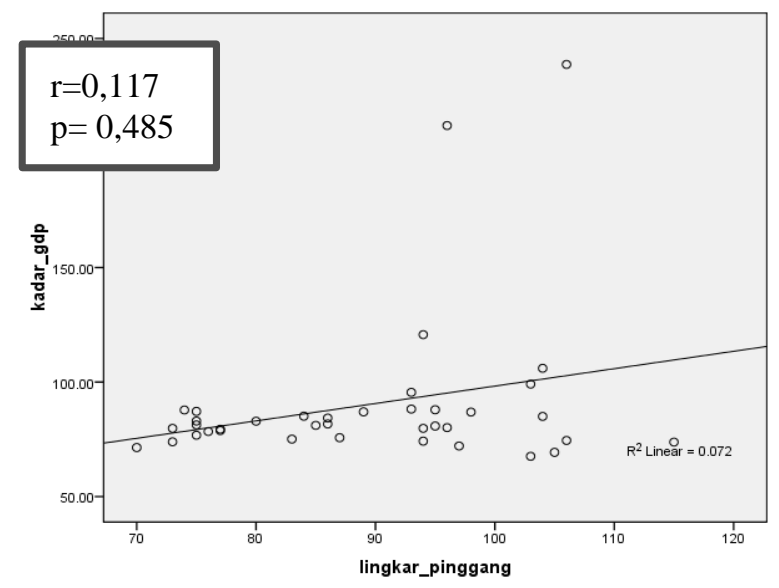

Gambar 2. Hubungan lingkar pinggang dengan kadar GDP

\section{Hubungan Aktivitas Fisik dengan Kadar} Glukosa Darah Puasa

Hasil penelitian menunjukkan tidak ada hubungan yang bermakna antara aktivitas fisik dengan kadar GDP ( $\mathrm{r}=0,68, \mathrm{p}=0,687)$. Hasil uji korelasi hubungan antara aktivitas fisik dengan kadar GDP dapat dilihat pada gambar 3. 


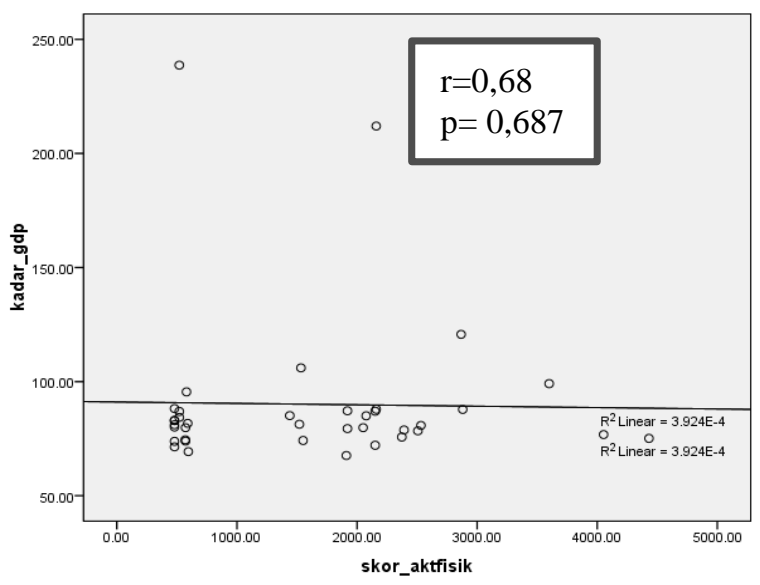

Gambar 3. Hubungan aktivitas fisik dengan kadar GDP

Hubungan Variabel Perancu (Asupan Zat Gizi) dengan Kadar Glukosa Darah Puasa
Tabel 4 menunjukkan bahwa tidak ada hubungan yang bermakna antara asupan energi, karbohidrat dan serat dengan kadar glukosa darah puasa.

Tabel 4. Hubungan Variabel Perancu (Asupan Zat Gizi) dengan Kadar Glukosa Darah Puasa

\begin{tabular}{lcc}
\hline Variabel & \multicolumn{2}{c}{ GDP } \\
\cline { 2 - 3 } & $\mathrm{r}$ & $\mathrm{P}$ \\
\hline Asupan energi & 0,197 & 0,236 \\
Asupan karbohidrat & $-0,102$ & 0,544 \\
Asupan lemak & 0,257 & 0,119 \\
Asupan serat & 0,071 & 0,674 \\
\hline
\end{tabular}

Rank spearman

\section{PEMBAHASAN}

Subjek penelitian ini adalah wanita dewasa usia 28-42 tahun. Sebagian besar subjek $(44,7 \%)$ bekerja sebagai ibu rumah tangga dan hampir seluruh subjek $(81,6 \%)$ tidak memiliki riwayat keluarga diabetes.

Rata-rata subjek memiliki kadar GDP normal yaitu 90,08 $\mathrm{mg} / \mathrm{dL}$, hampir seluruh subjek memiliki kadar GDP normal $(86,8 \%)$, terdapat 2 subjek $(5,3 \%)$ termasuk dalam kategori hipoglikemi, 3 subjek memiliki kadar GDP tinggi, satu subjek termasuk prediabetes $(2,6 \%)$ dan dua subjek $(5,3 \%)$ termasuk diabetes mellitus. Prevalensi nasional DM berdasarkan pemeriksaan gula darah pada penduduk usia $>15$ tahun diperkotaan $5,7 \%$. DM tipe 2 dapat terjadi di negara berkembang, peningkatan prevalensi terbesar adalah di Asia dan di Afrika, hal ini akibat perubahan gaya hidup seperti pola makan yang tidak sehat, berdasarkan hasil Riskesdas (2007) dari 24417 responden berusia > 15 tahun , 10,2\% mengalami toleransi glukosa terganggu (kadar glukosa $140-200 \mathrm{mg} / \mathrm{dL}$ setelah puasa selama 4 jam), DM lebih banyak ditemukan pada wanita dibanding dengan pria, lebih sering pada golongan tingkat pendidikan dan status sosial yang rendah.
Kadar glukosa darah dapat dipengaruhi oleh beberapa hal antara lain yaitu asupan makanan, aktivitas fisik, penggunaan obat-obatan, peningkatan stres dan emosi, genetik, serta obesitas. ${ }^{24,25}$

Hasil rata-rata pengukuran lingkar pinggang yaitu $89,24 \mathrm{~cm}$, sebagian besar subjek $(68,4 \%)$ tergolong dalam obesitas abdominal $(\geq 80 \mathrm{~cm})$ dan sebanyak 12 orang subjek $(31,6 \%)$ memiliki lingkar pinggang normal. Penelitian di Swiss, didapatkan hasil bahwa angka kejadian obesitas sentral pada wanita lebih banyak terjadi dibandingkan pria yaitu $30,6 \%$ dan $23,9 \%$. Beberapa penelitian menyebutkan bahwa obesitas baik obesitas secara general maupun obesitas abdominal memiliki prevalensi lebih tinggi pada wanita dibandingkan pria. Hal ini dapat disebabkan karena wanita lebih mudah mengontrol kelebihan energi dalam bentuk lemak sehingga menyebabkan wanita menjadi lebih mudah gemuk dan berdampak pada komposisi lemak tubuh wanita yang lebih tinggi dari pria dimana total lemak tubuh pada wanita berkisar antara 21-35\%. ${ }^{26,27,28}$

Subjek pada penelitian ini mengkonsumsi softdrink rata-rata $89,7 \mathrm{ml} /$ hari, sebagian besar subjek $(52,6 \%)$ mengkonsumsi $>1$ botol softdrink 
per minggu. Minuman ringan atau softdrink memberi kontribusi $7,1 \%$ dari total pemasukan energi. Tingginya kadar pemanis yang terkandung dalam softdrink dapat meningkatkan asupan kalori. $^{29}$

Rata-rata aktivitas fisik subjek adalah 1594,1 MET-menit/minggu, sebagian besar (50\%) subjek memiliki tingkat aktivitas fisik sedang. Secara nasional hampir separuh penduduk $(48,2 \%)$ kurang melakukan aktifitas fisik dan pada umur 1040 tahun $66,9 \%$ penduduk memiliki aktivitas kurang, perempuan $(54,5 \%)$ lebih tinggi dari lakilaki $(41,4 \%)$. Prevalensi kurang aktifitas fisik pada penduduk DM $>10$ tahun sebesar $48,2 \% .^{5}$

Hasil uji korelasi penelitian ini, tidak menunjukkan adanya hubungan yang bermakna antara konsumsi softdrink, lingkar pinggang, dan aktivitas fisik dengan kadar glukosa darah puasa. Sama halnya dengan hasil uji korelasi antara asupan zat gizi dengan kadar GDP dimana tidak ada hubungan yang bermakna antara asupan energi, karbohidrat, lemak dan serat dengan kadar GDP.

Rata-rata konsumsi softdrink subjek adalah $89,7 \mathrm{ml} /$ hari. Tidak ada hubungan yang bermakna antara konsumsi softdrink dengan kadar GDP $(\mathrm{r}=0,119, \mathrm{p}=0,477)$. Berbeda dengan beberapa penelitian yang menyebutkan bahwa konsumsi softdrink (minuman dengan pemanis) pada responden yang mengkonsumsi softdrink berhubungan dengan meningkatnya berat badan dan meningkatkan risiko penyakit diabetes mellitus tipe 2 dibandingkan dengan responden yang tidak mengkonsumsi softdrink. ${ }^{17,30}$ Hal ini dapat disebabkan karena perhitungan konsumsi softdrink hanya dilakukan dengan menghitung jumlah $\mathrm{ml}$ softdrink yang dikonsumsi subjek tanpa menghitung jumlah kandungan kalori dan gula yang terdapat pada berbagai macam softdrink yang dikonsumsi subjek, karena jumlah kandungan kalori dan gula yang ada pada softdrink dapat berbeda-beda di setiap kemasannya tergantung dari jenis softdrink yang dikonsumsi subjek.

Sebagian besar subjek mengalami obesitas abdominal. Proporsi lemak abdominal yang tinggi merupakan komponen yang penting dalam resistensi insulin dan diabetes mellitus. ${ }^{31}$ Namun, pada penelitian ini tidak dapat membuktikan obesitas abdominal berhubungan dengan kadar glukosa darah. Berbeda dengan penelitian oleh Hilary Bambrick yang menyebutkan bahwa lingkar pinggang berhubungan signifikan dengan peningkatan GDP. ${ }^{32}$

Sebagian besar subjek memiliki aktivitas fisik tingkat sedang. Aktivitas fisik sangat bermanfaat untuk meningkatkan sirkulasi darah, menurunkan berat badan dan memperbaiki sensitivitas insulin sehingga akan memperbaiki kadar glukosa darah. Aktifitas fisik yang kurang dapat menyebabkan tubuh mudah mengalami kegemukan, peningkatan kadar glukosa darah dan merupakan faktor risiko independen untuk penyakit kronis. $^{33,} 34$ Penelitian yang dilakukan oleh Sri Anani, membuktikan bahwa ada hubungan antara aktivitas fisik dengan kadar glukosa darah $(\mathrm{p}=0,012) .{ }^{35}$ Aktivitas fisik dapat sebagai upaya pencegahan peningkatan berat badan dan secara signifikan berkontribusi untuk menurunkan berat badan dalam jangka panjang dan mengurangi risiko kesehatan yang berhubungan dengan penyakit kronis seperti diabetes mellitus.

Tidak adanya hubungan yang bermakna dalam penelitian ini dapat disebabkan oleh faktor lain dalam peningkatan kadar glukosa darah seperti usia, faktor genetik dan lingkungan. Anggota keluarga penderita DM memiliki kemungkinan untuk mewarisinya dibandingkan dengan anggota keluarga yang tidak memiliki riwayat DM. $^{31}$ Kejadian DM tipe 2 banyak terjadi pada wanita usia diatas 50 tahun, usia yang tidak produktif, dimana pada usia ini terjadi penurunan berbagai fungsi tubuh dan gangguan berbagai macam penyakit. ${ }^{32}$ Disamping itu, kemungkinan bias dapat terjadi karena subjektifitas dalam pengisian kuisioner oleh subjek karena keterbatasan waktu yang dimiliki subjek sehingga subjek melakukan pengisian kuisioner mandiri dengan penjelasan singkat sebelumnya dan hanya berkomunikasi melalui sms dan telephone, peneliti kurang dapat bertanya lebih dalam. Selain itu, sehari sebelum pengukuran GDP peneliti sudah mengingatkan lewat SMS untuk berpuasa tapi tidak menjelaskan kembali berapa lama waktu puasa yang dianjurkan dan tidak menanyakan kembali berapa lama waktu puasa yang dijalani subjek sebelum diambil darahnya.

Walaupun konsumsi softdrink tidak berhubungan langsung dengan GDP namun didapatkan hasil bahwa ada hubungan yang bermakna antara konsumsi softdrink dengan lingkar pinggang subjek $(\mathrm{r}=0,407, \mathrm{p}=0,011)$. Sejalan dengan penelitian oleh Francis et al, bahwa subjek yang mengonsumsi minuman manis lebih dari 1 botol per hari dapat memiliki risiko untuk mengalami overweight sebesar 1.52 kali. ${ }^{36}$ Penelitian yang dilakukan oleh Collison et al. menjelaskan bahwa minuman Sugar-sweetened carbonated beverages (SSBs) termasuk didalamnya jenis softdrink berkorelasi dengan peningkatan indeks massa tubuh (IMT) dan peningkatan lingkar pinggang. ${ }^{37}$ Adanya hubungan antara konsumsi makanan manis dengan obesitas diduga karena 
kontribusinya terhadap total energi. Minuman manis berenergi menghasilkan asupan energi lebih tinggi daripada minuman manis dengan pemanis buatan. Penggantian minuman manis berenergi dengan minuman manis dengan gula buatan tidak mempengaruhi total asupan energi. Diet fruktosa berkontribusi pada peningkatan asupan energi dan berat badan. Minuman manis berenergi meningkatkan asupan energi yang berlebihan. Peningkatan konsumsi HFCS (high fructosa corn syrup) berhubungan dengan epidemi obesitas. HFCS biasa digunakan pada makanan produk bakeri, minuman kaleng, jam dan jelly. HFCS dan peningkatan asupan soft drink dan minuman manis lain berperan pada peningkatan total energi dan konsumsi fruktosa yang berkontribusi pada epidemi obesitas.

\section{SIMPULAN}

Konsumsi softdrink, lingkar pinggang dan aktivitas fisik tidak memiliki hubungan yang bermakna dengan kadar glukosa darah puasa pada wanita dewasa, tetapi konsumsi softdrin memiliki hubungan yang bermakna dengan lingkar pinggang pada wanita dewasa.

\section{SARAN}

1. Wanita dewasa perlu memperbaiki pola asupan makan dan membatasi konsumsi softdrink agar tercapai berat badan yang ideal dan terhindar dari berbagai macam penyakit di masa mendatang.

2. Untuk penelitian selanjutnya dapat lebih memperhatikan dan mengukur kandungan kalori dan gula pada softdrink.

3. Perlu ada penelitian lebih lanjut terhadap faktor risiko yang berhubungan dengan peningkatan kadar glukosa darah dengan cara kerja dalam penggunaan instrumen penelitian yang lebih baik.

\section{DAFTAR PUSTAKA}

1. Manaf A. Insulin : Mekanisme sekresi dan aspek metabolisme. Dalam : Buku ajar ilmu penyakit dalam jilid 4. Jakarta : Pusat Penerbit Departemen Ilmu Penyakit dalam Fakultas Kedokteran Universitas Indonesia ; 2006. Hal 1869 - 69.

2. Soegondo S. Prinsip pengobatan diabetes, insulin dan obat hipoglikemik oral. Jakarta : Pusat Diabetes dan Lipid RSCM-FKUI ; 2005.

3. National Diabetes Statistic Report. 2014. http://www.cdc.gov/diabetes. [cited 2015 February 23]

4. Kementrian Kesehatan. Petunjuk teknis pengukuran faktor risiko diabetes mellitus. Kementrian Kesehatan RI; 2008.
5. Dinas Kesehatan Kota Semarang. Profil kesehatan kota Semarang 2010. Semarang : Dinas Kesehatan Kota Semarang;2010.

6. Perkumpulan Endokrin Indonesia. Konsensus Pengelolaan dan pencegahan diabetes mellitus tipe 2 di Indonesia. Jakarta : PB. PERKENI; 2006. Hal 3-14, 30-31.

7. Soewondo P, Laurentinus AP. Prevalensi, charasteristic and predictor of prediabetes in Indonesia. Departement of Internal Medicine faculty of Medicine Universitas Indonesia; 2011; 20:283 - 293 .

8. American Diabetes Association, Inc. All about prediabetes. 2009. [cited 2015 February 23]

9. Hardiman S, Intan NV, Puspa KR, Eva S. Waist circumference as a predictor for blood glucose levels in adults. Universa Medicina. 2009 ; 28 (2) : 77-82.

10. Vidal PM, Murielle B, Vincent M, Fred P, Gérard W,Peter V. Prevalence of obesity and abdominal obesity in the lausanne population. BMC Public Health 2008, 8:330.

11. Janghorbani M, Masoud A, Walter CW, Mehdi G,Alireza D,Siamak A,Alireza M. First nationwide survey of prevalence of overweight, underweight, and abdominal obesity in iranian adults. Obesity. 2007[cited 2014 April 5];15:2797-2808.

12. F Supari. Metabolic Syndrome in Jakarta. Jurnal Majalah Kedokteran Indonesia vol 55 no.10. 2005 : hal 618-621.

13. Johnson RJ, Segal MS, Sautin Y, Nakagawa T, Feig DI, Kang DH, et al. Potential role of sugar (fructose) in the epidemic of hypertension, obesity, and the metabolic syndrome, diabetes, kidney disease, and cardiovascular disease.Am J Clin Nutr [Internet]. 2007 [cited 2014 April 10]; 86: 899-906.

14. Vijayakumar S. Consumer behaviour relating to carbonated softdrinks- edition:major supliers and brands [Internet]. 2010 [cited 2014 April 10]. P Just-drink, 19, 10-28.

15. Artikel Global Softdrink. Dari : http://www.zenithinternasional.com

16. Harper, Angela, et al. Increase satiety after intake of chocolate milk drink compared with a carbonated beverages, but no difference in subsequences ad libitium lunch intake. The British Journal of Nutrition. 2007[cited 2014 April 13].

17. J. James, D. Kerr. Prevention of childhood obesity by reducing softdrink. 2005[cited 2014 April 15].

18. Hardinsyah. Konsumsi minuman berkalori mengkhawatirkan. http//health.compas.com. 2011.

19. Slamet S. Kecenderungan peningkatan jumlah penyandang diabetes. Dalam : Sidartawan S, Pradana S, Imam S, editors. Penatalaksanaan diabetes melitus terpadu. Jakarta : Balai Penerbit FKUI; 2007.p.1-2.

20. Widajanti L. Buku petunjuk praktikum survei konsumsi gizi. Semarang : Bagian Prodi Magister Gizi Masyarakat Program Pascasarjana UNDIP.2007. 
21. Gibney, M.J. Gizi Kesehatan Masyarakat. Jakarta: EGC; 2009.

22. IPAQ. Guiedlines for Data Processing And Analysis of the International Physical Activity Questionnaire (IPAQ). 2005.

23. World Health Organisation. Diabetes mellitus : Report of a WHO Study Group. World Health Organisation. Geneva-Switzerland; 2006. S5-36.

24. Depkes. Riset Kesehatan Dasar. Profil Kesehatan Indonesia. 2007

25. Suyono S. Patofisiologi Diabetes Mellitus. Penatalaksaan Diabetes Mellitus Terpadu. Jakarta : FKUI. 2007.

26. Janghorbani M, Masoud A, Walter CW, Mehdi G,Alireza D,Siamak A,Alireza M. First nationwide survey of prevalence of overweight, underweight, and abdominal obesity in iranian adults. Obesity. 2007[cited 2014 September 25].;15:2797-2808.

27. Mahan KL, Sylvia Escott-Stump. Krause's Food, Nutrition, \& Diet Therapy. 11th ed. Philadelphia: Saunders; 2004.

28. Piche ME, Weisnagel SJ, Corneau L, Nadeau A, Bergeron J, Lemieux S. Contribution of abdominal visceral obesity and resistance to the cardiovasculer risk profile of postmenopausal women. Diabetes 2005[cited 2014 oktober 15];(54):750-7.

29. Sufiati B. Dampak negatif konsumsi junk-food. Dalam : Simposium Fast Food. Semarang 13 April 2003.

30. Palmer JR, Boggs DA, Krishnan S, et al. Sugar sweetened beverages and incidence of type 2 diabetes mellitus in African American women. Arch Intern Med 2008; 168: 1487 -92.

31. Martin IS, Marinho SP. The potential of central obesity antropometric indicators as diagnostic tools. Rev Saude Publica. 2003 [cited 2014 September 10]; 37:6.

32. Bambrick HJ. Relationship between BMI, waist circumference, hypertension and fasting glucose : Rethinking risk factors in Indigenous diabet. Australia indigenous health bulletin 2005.

33. Ramachandran A, Chamukuttan S. Diabetes melitus. Gizi Kesehatan Masyarakat. Gibney MJ et al [editor]. Jakarta : EGC;2008 : 407-19.

34. Mahendra, Krisnatuti, D., Tobing, A., \& Alting, Z. B. CareYour Self Diabetes Mellitus.Jakarta: Penebar Plus. 2008.

35. Sri Anani, dkk. Hubungan Antara Perilaku Pengendalian Diabetes Dan Kadar Glukosa Darah Pasien Rawat Jalan Diabetes Melitus (Studi Kasus Di RSUD Arjawinangun Kabupaten Cirebon). 2012 [cited 2015 Maret 12]

36. Damian K Francis, Jan Van den Broeck, Novie Younger, et al. Fast-food and Sweteened Beverage Consumption: Association with Overweight and High Waist Circumference in Adolescents. Public Health Nutrition 2009 [cited 2015 Maret 12] : 12(8), 1106-1114.

37. Kate S. Collinson, Marya Z. Zaidi, et al. Sugar sweetened carbonated beverages consumption correlate BMI, waist Circumference, and poor dietary choices in school children. 2010 [cited 2015 Maret 12] 